\title{
Jasmine and Lagarto: Pearse Hutchinson's Poetry of Spain
}

\author{
Vincent Woods
}

Copyright (c) 2010 by Vincent Woods. This text may be archived and redistributed both in electronic form and in hard copy, provided that the author and journal are properly cited and no fee is charged for access.

\begin{abstract}
In his life as a poet Pearse Hutchinson, now in his $84^{\text {th }}$ year, has engaged with the poetry and the cultures of many countries in Europe; at the heart of this work is his poetry of Spain. From his first visit there in 1950 to today Hutchinson has been inspired by the landscapes, people and languages of Spain, translating from Catalan, Castilian and Galician and writing memorable poems based on his own experiences and the history and politics of a country which he loves. His work brought an awareness of Spanish culture, life and literature to a wide audience in Ireland. Hutchinson is recording a prose memoir based on his life and travels in Spain and Portugal.
\end{abstract}

Key Words. Pearse Hutchinson, poetry, Ireland, Spain, Catalan, Barcelona, Galician, Gaelic, Franco, Mexico.

Resumen. En sus 84 años de vida Pearse Hutchinson se ha aproximado a muchas poesías y culturas europeas en su trayectoria poética. La poesía de España ocupa un lugar esencial en su obra. Desde su primera visita a la actualidad Hutchinson ha hallado inspiración en los paisajes, gentes y lenguas de España, traduciendo del catalán, castellano y gallego y escribiendo poemas memorables basados en sus propias experiencias y en la historia y política de un país al que ama. Su obra dio a conocer la cultura, literatura y realidad española a un amplio público irlandés. Hutchinson está grabando una memoria en prosa basada en su vida y viajes por España y Portugal.

Palabras clave. Pearse Hutchinson, poesía, Irlanda, España, catalán, Barcelona, gallego, gaélico, Franco, México.

Many Irish poets have engaged with a wider European landscape, poetic, linguistic, historical, metaphorical: we think of people like Denis Devlin, Michael Hartnett, Eva Bourke, Gabriel Rosenstock, Eiléan Ní Chuilleanáin and Michael Smith, to name a few. But outstanding in this context is the work of Pearse Hutchinson, now in his $84^{\text {th }}$ year and continuing to engage with the cultures, the politics, the languages and the poetics of countries like Spain, Portugal, and Italy - and the many distinct and separate identities and peoples within those countries. At the heart of this are his poems inspired by Spain and the different languages and peoples of that country.

Hutchinson's abiding interest in the languages and cultural identities of Europe began almost sixty years ago. In a sense it began even earlier. The poet himself credits his study of Latin and Irish at school in Synge Street in Dublin as part of the basis for both a love of languages and a grounding in the structure and grammar of Romance languages. He began to study Spanish in UCD in 1947 but says that a great deal of his knowledge of Spanish and French came through reading grammars and texts in the public libraries of Rathmines and Pembroke in Dublin.

There were earlier indications of an interest in Spain, albeit tentative or unformed. In his introduction to Done Into English, Collected Translations (Gallery Books, 2003) Hutchinson recalls writing a postcard to his mother from Scotland at the age of seven, saying: "When I grow up I'll take you to sunny 
Spain.” He says he has no idea where that thought came from. A few years later, at the age of eleven or twelve (1938 or 1939, so towards the end of the Spanish Civil War) his father took him to a public meeting in Dublin where a Basque priest, Father Laborda made "an impassioned speech in defence of the Spanish Republic" - this at a time when the Irish Catholic church (and many of the state's politicians) were firmly on the side of Franco.

Hutchinson first travelled to Spain in 1950, at the age of 23 arriving first in Vigo, then with his Trinidadian friend Bert Achong travelling to Andalusia - Seville, Granada, Córdoba. He has written that in those cities "the light walked for me as it never had before, and I walked through the light I'd always longed for." Smitten by the world of Lorca, of Prados, of Cernuda (though "Machado and Unamuno remained my favourites") the young Hutchinson left Ireland the following year, on April $1^{\text {st }}$, April Fool's Day 1951, determined to live in Spain forever.

Arriving in Madrid via Vigo and Lisbon he failed to get work and moved on to work at the ILO (International Labour Office) in Geneva, translating from Spanish and French. His train journey from Madrid to Geneva allowed him a twelve-hour stopover in Barcelona: so Pearse Hutchinson's first taste of that city was in late September or early October of 1951 and he recalls sitting on the Gaudí chairs on the Paseo de Gracia (as it was then) with very little money and half a bottle of white wine.

The connections to Spain and Hispanic poetry continued and broadened during Hutchinson's time in Geneva. Through colleagues at the ILO he met many Spanish Republican refugees living in exile in Switzerland after the Spanish Civil War and through them he met Octavio Paz, then an upand-coming poet who was First Secretary of the Mexican Embassy in Bern. They became acquaintances and remained in contact for many years. One of the refugees was Catalan and according to Hutchinson was a remarkably taciturn man. An English colleague told him that Catalans were "not really Spanish" and the Irishman was puzzled and intrigued. Hutchinson worked at the ILO for two years, going to Spain several times during this period, usually for two or three weeks, once travelling around Spain for six weeks. His first trip there had brought him back to Barcelona for a week or ten days early in 1952.
Hutchinson returned to Ireland in late 1953 and in September 1954 moved to Barcelona with his close companion Sammy (Daphne) Sheridan, who many years later published a fine collection of short stories, Captives, (under the pen name F.D. Sheridan) set in Spain and Italy. They had planned to work as English teachers through that winter and move to Andalusia in the spring. But they "fell in love with Barcelona.../ ... and never did get to Andalusia, except for six magnificent weeks in Pedregalejos, near Málaga, one summer.” In his two years living in Barcelona (also travelling through Germany, Holland, Denmark, Sweden and Italy) Hutchinson learned Catalan, met many Catalan writers and poets and began to translate poems from Catalan to English.

Hutchinson writes about this in some detail in that introduction to Done Into English. His presence in Barcelona in these years is also remembered by the English poet PJ (Patrick) Kavanagh in his memoir The Perfect Stranger: "He was a poet in a way that delighted and shocked me. He scribbled his poems in bars, and at bus stops and seldom changed them. The result was always exciting; I'd try to get him to correct a verse (it was easy to see I'd been to Oxford) and he'd agree, but he never did; instead he wrote another poem." Kavanagh was working for the British Institute in the city and in June 1955 arranged a reading of Catalan poetry with translations read by Hutchinson. The Catalan poets were Salvador Espriu, Carles Riba (who'd spent some of his exile in Dublin), Joaquim Horta, Blai Bonet and Marià Manent. This may have been one of the first official events in the city at which Catalan was used, acknowledged and in a sense honoured as a separate and living language within Franco's Spain.

Hutchinson returned to Ireland once again in 1957 but returned to Barcelona with his friend Ernie Hughes in 1961; soon after this he met the poet Pere Quart who joined the young Irishman and other Catalan poets, including Francesc Vallverdú in another reading at the British Institute in March 1962. Hutchinson's first published translations from Catalan were Thirty Poems by Josep Carner (Dolphin Books, Oxford, 1962) and he began to work on a commissioned translation of Salvador Espriu's "La pell de brau" (The Bull-skin) around this time. This book was never published though extracts from it appeared in Done into English 
and give some sense of Hutchinson's power as a translator.

from The Bull-skin

$$
1
$$

The bull, in the Sepharad ring, attacked the stretched skin and, tossing it high, made it a flag.

Against the wind, that blood-covered bull-skin is turned a rag the gold of the sun has thickened, forever giving over to the martyrdom of time, our prayer and blasphemy.

At once victim and executioner, hatred, love, lament, laughter, under a closed eternity of sky./...

Hutchinson later published Friends Songs (New Writers Press, 1970), a selection of Galico-Portuguese medieval song poems of love translated into English. The writer and radio producer David Thomson made a radio programme based on those poems for the BBC's Third Programme.

Pearse Hutchinson's first book of his own poems was published in 1963. Tongue Without Hands explores many territories of hope, memory, language and love. It has many poems inspired by his time in Spain, including the magnificent lyric poem Málaga, dedicated to his early love and travelling companion, the late Sammy Ryan (Daphne Sheridan). Here's the opening of that 24 line poem:

Málaga

The scent of unseen jasmine on the warm night beach.

The tram along the sea road all the way from town

through its wide open sides drank unseen jasmine down.

Living was nothing all those nights but that strong flower,

whose hidden voice on darkness grew to such mad power

I could have sworn for once I travelled through full peace

and eve love at last had perfect calm release only by breathing in the unseen jasmine scent, that ruled us and the summer every hour we went. /...
Colm Toibín chose "Málaga" as his favourite poem in one of the Lifelines collections published in Ireland several years ago, remarking on the way it captures the South. It's an extraordinary evocation of place, scent, heat, sensuality, of life far from the greyer skies and the many repressions of 1950s Ireland.

The collection contains poems either set in or inspired by Málaga, Palma de Mallorca, Córdoba, as well as Tomar, Paris and Geneva. None of these places or landscapes used simply for colour or effect - they are real, felt, almost absorbed landscapes - sometimes made metaphorical but always grounded in experience and considered thought. Spanish words and phrases occur ("Lengua sin manos, cuemo osas fablar?" i.e. "Tongue without hands, how dare you speak?” from the Poem of the Cid, used as epigraph to "Look, No Hands") and in the poem "This Country" Hutchinson conjures images of Spain (lagarto, chameleon, cicada) as representative of the country itself with its "youthful healing of some northern shame.../...A liberation from green fields..." Spain: "a real place, that could be loved and hated/half-understood, abused, accepted, left." Spain: a space wide enough to foster understanding, even love of home, of Ireland and of Gaelic poetry - "Chameleon, cicada, yellow bittern".

All six of Hutchinson's collections of poems in English published between 1963 and 1995 are gathered together in Collected Poems (The Gallery Press, 2002) along with eighteen new poems. A further collection At Least for a While (The Gallery Press) was published in 2008 and several new poems and translations have been printed in literary magazines since then. A brief survey of all this work in English allows one to see the depth and consistency of his engagement with Spain, its languages, cultures and peoples. I've calculated that approximately 46 of the 186 poems in Collected Poems concern Spain or address Hispanic themes; in addition nine poems At Least for a While reference Spanish concerns; while Done into English features 89 poems in translation from Galician (25), Spanish/ Castillian (9) and Catalan (55).

Poems like "Homage to José Martí" and "A Rose and a Book for Sant Jordi” (Watching the Morning Grow, 1972) remain fresh and urgent in re-reading, the former glowing with light and simple clarity, the latter a memorable 
account of a unique and brilliant form of communal protest against linguistic imperialism. That theme of the Catalan struggle to assert its right and place and language within Franco's Spain recurs in a much later poem of memory and homage, "Enriqueta Bru” (Barnsley Main Seam, 1995). The woman of the title worked as a secretary in an office where Hutchinson sometimes collected his wages for business-translation and one day:

she took our courage in her hands and showed me the big book she was reading:

El Crist de nou crucificat

Christ recrucified her own book

in her own tongue I'll never forget

the pride in her eyes in her quiet voice

telling me Salas had done it straight

from Greek not second-hand...

The poem is a tribute to one woman but also to generations of people who struggled to keep a language alive, who held to the hope of freedom and dignity.

In the poem "She Made her False Name Real" Hutchinson looks to the island of Mallorca and a popular rebellion in Palma in 1391 which the authorities managed to divert into a pogrom against the city's Jews. The forced conversion of many of the island's Jews and their re-naming as Christians takes up two constant themes in Hutchinson's work: the vicious and insidious nature of anti-Semitism and the wrong and injustice of misnaming people or places as a distortion of truth. With that poem in Climbing the Light (1985) is a companion poem of history and Christian tyranny "The Flames are False: Only the Hell is Real" about a Catalan schoolteacher who, in 1826, was hanged over cardboard cut-out flames as "a dogmatic heretic and perverter of youth" and whose last words were "Crec en Déu", "I believe in God".

Also in that collection is a dancing, celebratory poem of difference, defiance and contrast:

Andalusia

At blazing, sweating lunch-time

the Andalusian building-workers erupted into the Catalan pub

downing work-dry litres of black dirt-cheap wine

guzzling their own big sandwiches but first of all erupting six or seven at a time down the three steps from the narrow street glare into the officially cool Catalan shade;

some thought the noisy, others vital;

they cast their coins on the counter, making it ring!

looking the Catalan publican straight in the eye as much as to say, We're as good as you, and we can prove it

in your own lousy terms./...

Three prose poems, "The Most Beautiful Dog", "Eel" and "One of the Finest Things" in New Poems (1995-2001) see Hutchinson in retrospective mode, remembering younger days in Barcelona and Toledo. A Pyrenean mastiff called Noi in a bar on Vallirana, a young girl in Calella stroking an eel and praising its beauty, and an emerald-green lizard who "shot out from the parapet at the speed of light" are vivid images of Spain, a country vividly different to Ireland. Yet threaded through the poems is a sense of connectedness, of connections between Spain (or the many Spains the poet knew) and Ireland. The terrible poverty and desolation of the poem "A Girl in Jerez de la Frontera, in the Autumn of 1952" is like a mirror to "Vincent de Paul, Dublin 1946". The eleven year-old girl offering her body for sale for "Un duro," a five-peseta coin shares the same hard, hopeless life as the "small, old man/completely hairless/cowering, quivering/in a grey room...” Two lives linking two Catholic countries reeking of need, want and exploitation.

Those connections are seen again in "The Three-Cornered Hat” (At Last for a While) where a Guardia Civil in Seville in 1951 draws up a chair to sit beside the young Irishman and having found out where he came from, smiled and said: "El alcalde que no quiere comer" (The mayor who doesn't want to eat.) Hutchinson writes:

The point of the grim joke being (grim

for Spaniards and Irish alike): that was a headline in a Spanish

newspaper when Terence McSwiney, Lord Mayor of Cork

died on hunger strike for Irish freedom.

Whereas Spanish mayors were a byword for gluttony -

and other forms of rapacity. In a Spain full of hungry people./..

Hutchinson's increasing focus on Galicia and Galician is evident in two poems in At Least for a While: "Teaching Mathematics" 
about a teacher wearing black to school in protest against an election victory for a rightwing political party and "Black Tide" about another protest, when ten people lay naked on the oil-besmeared coast of Galicia after the Prestige oil tanker disaster in March 2002. Both poems capture a contained but intense anger, a sense of dignified determination.

Another poem in that collection, "Believers in a Possible Freedom" echoes a story in the Galician novel Os libros arden mal ("Books Burn Badly") by Manuel Rivas. It details a visit to the grave of an old Republican by a group of friends on the $14^{\text {th }}$ of April 1931 ("the very day the Republic got declared") and one of them placing flowers on the gravestone and telling "their old comrade in hope/The Republic has come!/The Republic has come!" Hutchinson's poem is set in Lugo, the short scene in Rivas's novel occurs in Coruña - the characters and setting may be different but the sentiment is the same.

Hutchinson's Hispanic world of poetry encompasses many of the countries of Spanish conquest, colonisation and Diaspora. In "Prose" (Expansions, 1969) an Anarchist poet in exile after the Spanish civil war is asked by the University of Caracas to give a public course of poetry talks, asks for a fee of 2,000 dollars and scatters the money ("one note in ten diligently torn into neat fragments") to a large crowd in the public square. Various other poems reference Cuba, Mexico and other Central and South American countries; Done into English includes a translation of one poem by Octavio Paz and since then Hutchinson has published a number of translations of work by other Mexican poets.

Hutchinson's poetry in Gaelic also contains many powerful poems with themes drawn from Spanish life, history, politics and people. "Pálás na hÉagóra nó Tobar na Fáinleoige"(in English "The Palace of Injustice or The Swallow's Well") remembers the fear and repression of Franco's rule ("El Palacio de Justicia” called "El Palacio de In-justicia” by a taxi-man in Barcelona; while "Is Trua nach Loscáin Sinn” (“A Pity We're Not Frogs”) recalls "an old poet” (Pere Quart) in that same city stretching his hand up towards the sky and saying (of Franco) "He can never,/...take that away from us/that sun up there,/.../that's the only thing he can't take from us." Another Gaelic poem "Nuair is faide é an teideal..." ("When the title is longer...") celebrates poetry and cakes and the trains of Barcelona; while "Dóchas Beag na hEagla” ("Hope, tho' Small, by Courtesy of Fear") links repression and fear in Chile and Spain to a period of political repression in Ireland. All of these poems with English versions by the poet himself can be found in The Soul that Kissed the Body (The Gallery Press, 1990)

In the context of translation it should also be noted that Hutchinson has translated poems from Catalan, Castilian and Galician into Gaelic; and says that the Catalan poet Salvador Espriu told him it meant far more to him to have one of his poems translated into Gaelic than into English.

After an absence of 26 years Hutchinson returned to Barcelona in April 1995 to read at the Festival Internacional de Poesia at the Palau de la Música. That year's festival was directed by the poet Àlex Susanna (who has written a poem about Pearse Hutchinson in Dublin; and some of whose work has been translated into English by Hutchinson) and featured thirteen poets: Catalan, Castilian, Argentine, Swedish, Finnish, Sardinian and Greek as well as Irish. Hutchinson dedicated that reading to "the two closest Catalan friends of my life: Josep Quaralt i Clapes and Toni Turull (Quaralt, originally from Badalona, cofounded the publishing house Proa and continued to run it from exile in Perpignan; the poet Toni Turull left Spain when he couldn't take any more of Franco's dictatorship and lived and taught in England). Hutchinson says he was deeply moved at the response to his reading and was very happy to return to a city he had loved so well in the new and established freedoms of post-Franco Spain.

A number of books of selected translations of Hutchinson's work have appeared in Castilian and Galician but so far no edition in Catalan. El alma que besó al cuerpo (translations from Hutchinson's Gaelic poems) was published by Hiperión in 1994 and later this year a selection of sixty of his poems in translation into Spanish are due to be published in Argentina. These translations are by Jorge Sagastume of Dickinson College, Carlisle, Pennsylvania, who edits the magazine Sirena in which a number of Hutchinson's own original poems have been published. The Galician translations are collected in Achnasheen: Corenta e catro poemas irlandeses (Noitarenga, 2002) and Lenda (Amastra-N-Gallar, 2004, published by Emilio 
Araúxo with translations by Robert Neal Baxter.)

This article is intended more as an introduction to Hutchinson's Spanish work than a comprehensive study of it. A more scholarly or academic analysis of this aspect of his poetry is overdue and will be a welcome addition to a comprehensive overview of his work. Anyone who wishes to get a brief but very informed overview of some of the richness and scope of the poems should read Trinity College scholar and lecturer Philip Coleman' fine article "At Ease With Elsewhere" published in the online literary magazine The Dublin Review of Books (http://www.drb.ie/more_details/09-09-28/At_ Ease_With_Elsewhere.aspx). The article gives an insight into the fullness of Hutchinson's engagement with a wide range of poetic cultures and contexts - Irish, Gaelic, English, Scottish, Portuguese, Italian, Dutch and French, as well as Spanish and Hispanic. In that article Coleman puts forward the idea that we might consider Pearse Hutchinson as a "transnational" poet, insofar as his work exemplifies the kind of "poetic transnationalism" that the American critic Jahan Ramazani has suggested "can help us both to understand and imagine a world in which cultural boundaries are fluid, transient and permeable".

I think this is a valuable and valid suggestion. Hutchinson has always written as one aware of boundaries - cultural, political, linguistic, sexual, national - and who has sought, through his work, to question the legitimacy of those boundaries, to examine and interrogate their origins and structure, to suggest ways of crossing them, or ways, indeed, of breaking them down altogether. We see that time and again in his poetry of Spain: the recognition of separate languages and cultures, the expression of anger at simplistic centralism, the need to seek and tell the truth from the past, the importance of the proper naming and acknowledging of things and people. But with all that a deep sense of fairness and equality, of respect for individual freedoms and voices, a recognition for the need to rejoice in the sometimes intense beauty of life, especially in the heat and sunlight of the South. Philip Coleman and Maria Johnston (also from Trinity College) are editing a book of essays and reflections on Pearse Hutchinson's work, due for publication in late 2010. This will include a long interview with the poet, a comprehensive bibliography of his work and essays on his career as poet, translator, critic, reviewer and broadcaster. It will contain a number of pieces on his Spanish poems and translations, including "The Irish Poet and the English Gentleman”, a paper given by the poet Francesc Parcerisas to the Anglo-Catalan Society in London in 2002; an essay on Hutchinson's translation work in Barcelona in the 1950s and 1960s and his involvement with the publisher Joan Gili who established Dolphin Books in Oxford.

The young boy who wrote to his mother promising her a trip to Spain, the young man who discovered the light and beauty and passion of that country, the poet who found new languages and a new love for old languages in the streets and bars of Barcelona has become an old man with an acute memory of it all. Hutchinson is recording a prose memoir of his time and travels in Spain and Portugal; I've heard some of it and it is as vivid and remarkable as the best of his poems. Spain has been at the core of Pearse Hutchinson's life and it remains there: the Spain of the heart, the soul and the mind. A poet's Spain, linked to Ireland and made real and imaginable for those of us who have travelled with him on the page only.

Vincent Woods is an Irish poet, playwright and broadcaster. His plays include At The Black Pig's Dyke and A Cry from Heaven. Poetry collections are The Colour of Language and Lives and Miracles. He presents a weekly arts programme, Arts Tonight on RTE 1 Radio (www.rte.ie) He lives in Dublin and is a member of Aosdána, the Irish Academy of Artists. 